\title{
Mesoscale variability in bacterial activity in the Northeast Pacific Ocean off Oregon, USA
}

\author{
Evelyn B. Sherr*, Barry F. Sherr, Timothy J. Cowles \\ College of Oceanic and Atmospheric Sciences, Oregon State University, Corvallis, Oregon 97330-5503, USA
}

\begin{abstract}
Variation in bacterial abundance and activity was assessed by sampling the upper 35 to $80 \mathrm{~m}$ of the water column during 2 to $5 \mathrm{~d}$ periods at 3 sites: eutrophic-mesotrophic midshelf, mesotrophic-oligotrophic slope, and oligotrophic gyre edge, off the Oregon coast in late summer 1997 and 1998. Bacterial abundances varied 10-fold, from 0.2 to $2.3 \times 10^{6} \mathrm{cells} \mathrm{ml}^{-1}$, and leucine incorporation rates varied 160 -fold, from 1.5 to $240 \mathrm{pM} \mathrm{h}^{-1}$. During the strong El Niño event in 1997, bacterial abundances were similar at all 3 sites, but midshelf ${ }^{3} \mathrm{H}$-leucine incorporation rates were $\sim 6$-fold higher than rates at the slope and gyre sites. In 1998, after relaxation of the El Niño, bacterial abundances were lower, and average ${ }^{3} \mathrm{H}$-leucine incorporation rates were only 2.5 times higher at the midshelf site than at the slope and gyre sites. There was a close correlation between estimates of bacterial cell production rate based on ${ }^{3} \mathrm{H}$-leucine and on ${ }^{3} \mathrm{H}$-thymidine incorporation rates for the midshelf and slope sites, but no relation between the 2 estimates for the gyre site. During both years, bacterial abundance varied inversely with depth, salinity, and macronutrients and positively with temperature. Bacterial activity varied positively with chlorophyll concentration, temperature, and bacterial biomass. Rates of bacterial ${ }^{3} \mathrm{H}$-leucine incorporation were most strongly related to chlorophyll concentrations at the midshelf site and less related at sites farther offshore. There was no significant relation of bacterial parameters with the concentration of dissolved organic carbon. Our results showed dynamic mesoscale variability, on scales of 10 s of meters to 10s of kilometers, and on scales of hours to days in rates of bacterial activity, which was positively related to phytoplankton concentration as a proxy for trophic state of the water mass. We also found inter-annual differences in distribution of bacterial abundance and activity in this region, which appeared to be related to climatic variability.
\end{abstract}

KEY WORDS: Marine bacteria $\cdot$ Bacterial activity $\cdot$ Mesoscale $\cdot$ El Niño $\cdot$ Northeast Pacific

\section{INTRODUCTION}

The activity, i.e., growth rate and rate of production of carbon biomass, of heterotrophic bacterioplankton has been measured as the rate of incorporation of radiolabeled substrates across a wide range of aquatic ecosystems. That bacterial activity shows much greater variability than bacterial standing stock and is positively related to ecosystem trophic state is now well established (Cole et al. 1988, Billen et al. 1990, Ducklow \& Carlson 1992). However, within single aquatic ecosystems there is often only a weak relation between

*E-mail: sherre@oce.orst.edu bacterial standing stocks or activity and potential bottom-up controls such as phytoplankton biomass and concentration of dissolved organic carbon (Ducklow 1992, Ducklow \& Shiah 1993, Pace \& Cole 1994, Sherr et al. unpubl. data). As Ducklow (2000) has stated: 'We do not have a satisfactory theory of the regulation of bacterial stocks and production in the sea.'

One facet of this problem with respect to open ocean systems is that we do not have a good understanding of the extent and causes of variation in bacterioplankton parameters at mesoscales of time and space. Sampling for marine bacterial abundance and productivity is generally over kilometer-scale distances, as in the Joint Global Ocean Fluxes Study programs, or at time scales of weeks to years, as in the Bermuda Atlantic 
Time Series (e.g., Ducklow et al. 1993, Carlson et al. 1996, Ducklow 2000). Studies specifically designed to analyze change in bacterial standing stocks and rates of substrate incorporation, over time scales of hours and depth scales of meters, at 1 specific location in an open ocean habitat are rare. Gasol et al. (1998) carried out one such study in the eastern Mediterranean and found substantial diurnal variability in rates of leucine incorporation by bacteria.

Here we report variation in both bacterial abundances and rates of incorporation of radiolabeled substrates in the upper 35 to $80 \mathrm{~m}$ of the water column over periods of 2 to $5 \mathrm{~d}$, at 3 sites off the Oregon coast: a midshelf site in the eutrophic to mesotrophic upwelling system, a site at the mesotrophic to oligotrophic shelf slope, and a site at the edge of the oligotrophic North Pacific central gyre. We compared the bacterial parameters with environmental parameters at each site, and compared the pattern of distribution of bacterial stocks and activity across sites during a strong El Niño period in 1997 when upwelling of nutrient-rich water was reduced, and during a more normal upwelling season in 1998 (Huyer et al. 1998, Kosro et al. 1998, Wheeler \& Hill 1998, Wheeler \& Corwith 1999).

\section{METHODS}

Sampling. Water samples were collected during 2 cruises along the Newport sampling line off the Oregon coast, USA (Huyer \& Smith 1985, Huyer et al. 1998): September 6 to 18, 1997, and August 31 to September 18, 1998. In each cruise, the ship remained on station for 3 to $6 \mathrm{~d}$ periods at 3 locations: midshelf $\left(44^{\circ} 38.3^{\prime} \mathrm{N}, 124^{\circ} 18.5^{\prime} \mathrm{W}, \sim 20 \mathrm{~km}\right.$ from the coast, bottom depth $80 \mathrm{~m})$; slope $\left(44^{\circ} 38.3^{\prime} \mathrm{N}, 124^{\circ} 48.0^{\prime} \mathrm{W}\right.$, $\sim 60 \mathrm{~km}$ from the coast, bottom depth $350 \mathrm{~m}$ ); and gyre edge $\left(44^{\circ} 38.65^{\prime} \mathrm{N}, 127^{\circ} 10^{\prime} \mathrm{W}, \sim 240 \mathrm{~km}\right.$ from the coast, bottom depth $>2000 \mathrm{~m}$ ). Samples for analysis of water chemistry and biological parameters were collected with either a conventional CTD rosette equipped with 101 Niskin bottles or a free-falling CTD/fluorescence profiler equipped with a mini-rosette of 0.51 sampling bottles. The upper 50 to $80 \mathrm{~m}$ of the water column at each site was sampled at a spatial resolution of 2 to $20 \mathrm{~m}$ depth intervals and a temporal resolution of 4 to $20 \mathrm{~h}$, with more frequent sampling during the day.

Environmental parameters. Temperature and salinity were determined from calibrated sensors on SeaBird 911 CTD systems (Sea-Bird Electronics, Bellevue, WA, USA). Subsamples of seawater for inorganic nutrients were frozen and later thawed and analyzed for inorganic nutrients by standard wet chemical methods according to the protocols of Gordon et al. (1995). Nitrate samples were run on an Alpkem RFA-300 (OI
Corporation, College Station, TX, USA), and phosphate was run on a Technicon AA-II autoanalyser (TechniCon Corporation, Emeryville, CA, USA). Subsamples for total organic carbon determination were frozen in clean plastic bottles and later thawed, acidified with phosphoric acid, and analyzed by high temperature combustion with a Shimadzu TOC-500 Shimadzu Scientific Instruments, Columbia, MD, USA). Chl a concentrations were determined fluorometrically after $24 \mathrm{~h}$ extraction in $90 \%$ methanol at $5^{\circ} \mathrm{C}$ (Parsons et al. 1984).

Bacterial abundance. Duplicate $2 \mathrm{ml}$ aliquots of each sample were fixed with a $5 \%$ concentration of boratebuffered formalin, stained with $25 \mu \mathrm{g} \mathrm{ml}^{-1}$ DAPI, settled onto two $0.2 \mu \mathrm{m}$ black polycarbonate filters that were mounted on a glass slide, and stored frozen until later enumeration of bacterial cells by epifluorescence microscopy (Sherr et al. 1999a).

Bacterial incorporation of leucine and thymidine. Rates of incorporation into macromolecules of tritiated leucine and of tritiated thymidine in 1998 were assessed using the centrifugation method of Smith \& Azam (1992). For each sample, triplicate $1.7 \mathrm{ml}$ aliquots were pipetted into $2 \mathrm{ml}$ microcentrifuge tubes. A fourth aliquot in each set was amended with $5 \%$ final concentration TCA as a killed control. Final concentrations of $20 \mathrm{nM}\left[{ }^{3} \mathrm{H}\right] 3,4,5$-leucine $\left(\left[{ }^{3} \mathrm{H}\right]-l e u, \mathrm{NEN}\right.$ Life Science Products (Boston, MA, USA), NET460, $\left.159 \mathrm{Ci} \mathrm{mmol}^{-1}\right)$ or $10 \mathrm{nM}$ [methyl- $\left.{ }^{3} \mathrm{H}\right]$-thymidine $\left(\left[{ }^{3} \mathrm{H}\right]-\right.$ TdR, NEN Life Science Products, NET512, 102.8 Ci $\mathrm{mmol}^{-1}$ ) were added to live samples and the killed control. These were saturating concentrations as determined by concentration-dependent incorporation experiments carried out at the 3 sites. The TCA and isotope were added to the tubes before addition of sample to ensure rapid and complete mixing.

The microcentrifuge tubes were inserted into foam discs (PGC Scientific Corp, Frederick, MD, USA) and incubated for $1 \mathrm{~h}$ in the dark in small plastic coolers containing water at the in situ temperatures of the depths sampled. Incubation was terminated by addition of $89 \mu \mathrm{l}$ of $100 \%$ TCA to live samples (5\% TCA final concentration). Killed samples were processed within $24 \mathrm{~h}$. Until processing, [ $\left.{ }^{3} \mathrm{H}\right]$-leu samples were stored at laboratory temperature $\left(16\right.$ to $\left.21^{\circ} \mathrm{C}\right)$, and $\left[{ }^{3} \mathrm{H}\right]-$ TdR samples were kept at $-2^{\circ} \mathrm{C}$. Processing followed the protocol of Smith \& Azam (1992), except that the $5 \%$ TCA and $80 \%$ ethanol reagents were kept ice cold, and we used a refrigerated centrifuge set at $2{ }^{\circ} \mathrm{C}$, as recommended for $\left[{ }^{3} \mathrm{H}\right]-\mathrm{TdR}$ protocols (Bell 1993). After addition of $0.5 \mathrm{ml}$ of Ultima-Gold scintillation cocktail (Packard Biosciences, Meriden, CT, USA), each microcentrifuge tube was placed in a $7 \mathrm{ml}$ plastic scintillation vial. Activity in the samples was determined by 30 min counts on a Wallac 1411 LSC (PerkinElmer- 
Wallac Inc., Gaithersburg, MD, USA). Killed control demolitions $\min ^{-1}$ (DPM) was subtracted from the average of triplicate live DPM, and molar incorporation rates of $\left[{ }^{3} \mathrm{H}\right]$-leu and $\left[{ }^{3} \mathrm{H}\right]$-TdR were calculated. Empirical conversion factors determined by incubation experiments at each site during the 1998 cruise (Sherr et al. 1999a) were used to calculate rates of bacterial cell and biomass production. The conversion factors for the midshelf, slope, and offshore sites, respectively, were $2.2,1.4$, and $1.3 \times 10^{18}$ cells mol$^{-1}$ of TdR incorporated and $1.2,0.9$, and $0.2 \times 10^{17}$ cells mol $^{-1}$ of $\left[{ }^{3} \mathrm{H}\right]$-leu incorporated. Cell production rates were converted to rates of bacterial biomass production assuming a carbon content of $20 \mathrm{fg} \mathrm{C}$ bacterial cell ${ }^{-1}$, based on previously reported cell sizes of 0.1 to $0.16 \mu^{3}$ in these waters during late summer (Suzuki et al. 1993).

Cell-specific $\left[{ }^{3} \mathrm{H}\right]$-leu and $\left[{ }^{3} \mathrm{H}\right]$-TdR incorporation rates were calculated using bacterial abundances determined for each water sample. Bacterial growth rates $(\mu)$ were calculated from the equation $\mu\left[\ln N_{\mathrm{f}}-\ln \right.$ $\left.N_{0}\right] / d$, where $N_{0}$ is the standing stock bacterial cell abundance and $N_{\mathrm{f}}$ is the standing stock abundance plus daily increment of cell abundance calculated from $\left[{ }^{3} \mathrm{H}\right]$-leu or $\left[{ }^{3} \mathrm{H}\right]-\mathrm{TdR}$ incorporation rates. Bacterial assemblage doubling times $\left(T_{\mathrm{d}}\right)$ were estimated as $T_{\mathrm{d}}=$ $0.693 / \mu$.
Statistical analysis. Relations between bacterial cell production rates based on $\left[{ }^{3} \mathrm{H}\right]$-leu and $\left[{ }^{3} \mathrm{H}\right]$-TdR incorporation, and relations between bacterial $\left[{ }^{3} \mathrm{H}\right]-$ leu incorporation rates and chlorophyll a ( $\mathrm{chl} a$ ) concentrations were determined by linear regression analysis. Spearman rank correlation coefficients were calculated using SigmaStat software (Jandel Scientific Software, San Rafael, CA, USA) to evaluate the relations between bacterial abundance, bacterial activity, and the environmental parameters analyzed for each station and year. To ensure normal distribution, data were transformed to natural logarithms before rank correlation analysis was performed.

\section{RESULTS}

\section{Environmental conditions}

There were clear differences between sampling sites and between years for the suite of environmental parameters assayed (Table 1). During the 1998 cruise, parameters in the upper $30 \mathrm{~m}$ were averaged over 3 time periods at the midshelf site: August 31 to September 2, September 3 to 5, and September 19 to 20; and for 2 time periods at the slope site: September 12 to 14 and

Table 1. Comparison of environmental parameters at the midshelf, slope, and gyre sites at 0 to $30 \mathrm{~m}$ and 50 to $80 \mathrm{~m}$ depths during September 1997 and September 1998. Data are mean \pm 1 SD. 1998 data were separated into 3 time periods at the midshelf site: (a) August 31 to September 2, (b) September 3 to 5, and (c) September 19 to 20; and into 2 time periods at the slope site: (a) September 12 to 14, and (b) September 15 to 17. nd: no data

\begin{tabular}{|c|c|c|c|c|c|c|}
\hline Site & Temp. $\left({ }^{\circ} \mathrm{C}\right)$ & Salinity (psu) & Nitrate $(\mu \mathrm{M})$ & Phosphate $(\mu \mathrm{M})$ & DOC $(\mu \mathrm{M})$ & Chl a $\left(\mu g \mathrm{l}^{-1}\right)$ \\
\hline \multicolumn{7}{|l|}{1997} \\
\hline \multicolumn{7}{|l|}{ Midshelf } \\
\hline $0-30 \mathrm{~m}$ & $14.7 \pm 2.6$ & $32.3 \pm 0.4$ & $3.5 \pm 3.0$ & $0.70 \pm 0.38$ & \multirow[t]{2}{*}{ nd } & $2.8 \pm 1.4$ \\
\hline $50-80 \mathrm{~m}$ & $8.7 \pm 0.1$ & $33.6 \pm 0.0$ & $25.7 \pm 0.6$ & $2.3 \pm 0.04$ & & $0.17 \pm 0.09$ \\
\hline \multicolumn{7}{|l|}{ Slope } \\
\hline $0-30 \mathrm{~m}$ & $15.9 \pm 2.6$ & $31.9 \pm 0.4$ & $0.70 \pm 0.31$ & $0.36 \pm 0.19$ & \multirow[t]{2}{*}{ nd } & $0.59 \pm 0.12$ \\
\hline $50-80 \mathrm{~m}$ & $9.4 \pm 0.1$ & $32.8 \pm 0.1$ & $12.6 \pm 1.0$ & $1.2 \pm 0.7$ & & $0.16 \pm 0.07$ \\
\hline \multicolumn{7}{|l|}{ Gyre } \\
\hline $0-30 \mathrm{~m}$ & $18.5 \pm 0.6$ & $32 \pm 0.3$ & $0.04 \pm 0.02$ & $0.26 \pm 0.08$ & \multirow[t]{2}{*}{ nd } & $0.24 \pm 0.08$ \\
\hline $50-80 \mathrm{~m}$ & $10.6 \pm 0.5$ & $32.6 \pm 0.1$ & $3.4 \pm 2.4$ & $0.68 \pm 0.12$ & & $0.24 \pm 0.09$ \\
\hline \multicolumn{7}{|l|}{1998} \\
\hline \multicolumn{7}{|l|}{ Midshelf } \\
\hline $0-30 \mathrm{~m}, \mathrm{a}$ & $9.4 \pm 0.4$ & $33.2 \pm 0.1$ & $17 \pm 3$ & $1.5 \pm 0.2$ & $104 \pm 45$ & $6.2 \pm 2.7$ \\
\hline $0-30 \mathrm{~m}, \mathrm{~b}$ & $9.3 \pm 0.3$ & $33.1 \pm 0.2$ & $18 \pm 4$ & $1.6 \pm 0.2$ & $62 \pm 4$ & $0.75 \pm 0.5$ \\
\hline $0-30 \mathrm{~m}, \mathrm{c}$ & $11.9 \pm 1.6$ & $32.4 \pm 0.4$ & $5.7 \pm 4.7$ & $0.70 \pm 0.35$ & $87 \pm 21$ & $2 \pm 0.7$ \\
\hline $50-80 \mathrm{~m}$ & $8.2 \pm 0.2$ & $33.7 \pm 0.1$ & $28 \pm 1$ & $2.1 \pm 0.1$ & $85 \pm 31$ & $0.11 \pm 0.06$ \\
\hline \multicolumn{7}{|l|}{ Slope } \\
\hline $0-30 \mathrm{~m}, \mathrm{a}$ & $14.7 \pm 1.5$ & $32.1 \pm 0.2$ & $0.03 \pm 0.03$ & $0.28 \pm 0.05$ & $119 \pm 37$ & $0.44 \pm 0.11$ \\
\hline $0-30 \mathrm{~m}, \mathrm{~b}$ & $14.4 \pm 0.8$ & $32.1 \pm 0.1$ & $0.08 \pm 0.02$ & $0.30 \pm 0.06$ & $133 \pm 12$ & $0.87 \pm 0.25$ \\
\hline $50-80 \mathrm{~m}$ & $9.5 \pm 0.1$ & $32.8 \pm 0.1$ & $10 \pm 3$ & $1 \pm 0.2$ & $104 \pm 52$ & $0.16 \pm 0.05$ \\
\hline \multicolumn{7}{|l|}{ Gyre } \\
\hline $0-30 \mathrm{~m}$ & $18.2 \pm 0.3$ & $31.8 \pm 0.1$ & $0.05 \pm 0.02$ & $0.18 \pm 0.90$ & $90 \pm 18$ & $0.53 \pm 0.10$ \\
\hline $50-80 \mathrm{~m}$ & $10.5 \pm 0.4$ & $32.6 \pm 0.0$ & $1.8 \pm 1.3$ & $0.60 \pm 0.90$ & $103 \pm 39$ & $0.23 \pm 0.07$ \\
\hline
\end{tabular}


September 15 to 17 . During these time periods there were either distinctive changes in water mass or discrete continuous sampling periods. The influence of the Columbia River plume (salinity values $<32.5 \mathrm{psu}$ ) was detectable in the upper water masses at all 3 sites (Table 1). In the upper $30 \mathrm{~m}$, which generally comprised most of the mixed layer, temperatures were on average $5^{\circ} \mathrm{C}$ higher at the midshelf site and $\sim 1^{\circ} \mathrm{C}$ higher at the slope site during the El Niño conditions of 1997 compared with the more typical climatic conditions of 1998. Temperatures at the gyre edge site and the depth zone of 50 to $80 \mathrm{~m}$ for all 3 sites did not differ between years (Table 1). Variations in average concentrations of nutrients followed the temperature variations, as expected for an upwelling ecosystem, and nutrient concentrations in the upper $30 \mathrm{~m}$ decreased with distance from the coast. During 1997, there were much lower nitrate and phosphate concentrations in the upper $30 \mathrm{~m}$ of the midshelf site compared with conditions in 1998 (Table 1). In 1998, phytoplankton biomass at the midshelf site was more variable, with 1 period of fairly intense bloom, compared with the distribution of phytoplankton in 1997 (Table 1). Conditions at the slope and gyre sites were mesotrophic to oligotrophic in terms of nutrient and chl a concentrations during both cruises. No apparent pattern emerged for distribution of DOC during the 1998 cruise; high concentrations (>80 $\mu \mathrm{M})$ were found at all sites and depths.

\section{Variability in bacterial abundance and activity}

An example of patterns of variation in bacterial abundance $\left(10^{6}\right.$ cells ml $\left.{ }^{-1}\right)$ and in rates of $\left[{ }^{3} \mathrm{H}\right]$-leu incorporation (pM leu $\mathrm{h}^{-1}$ ) with time and depth is shown for the midshelf site in Fig. 1. There was considerable variation, both in abundance and in rates of $\left[{ }^{3} \mathrm{H}\right]$-leu incorporation, at scales of hours and of 2 to $20 \mathrm{~m}$ depth intervals for all the sites. Isolated single-depth and time hotspots of high bacterial activity were found during midshelf (Fig. 1) and slope (data not shown) sampling periods. A noticeable short-term change in distribution of abundance and activity was observed at the midshelf site during August 31 to September 5, 1998 (Fig. 1C,D). At the outset of this sampling period, there were high chl a concentrations $\left(6.2 \pm 2.7 \mu \mathrm{g}^{-1}\right)$, and rates of leu incorporation were also high. On August 3, however, a surface water mass with considerably lower chl a concentrations $\left(0.75 \pm 0.50 \mu \mathrm{g} \mathrm{l}^{-1}\right)$ moved
Fig. 1. Patterns of variation in bacterial abundance $\left(10^{6} \mathrm{cells} \mathrm{ml}^{-1}\right)$ and in rates of $\left[{ }^{3} \mathrm{H}\right]$-leu incorporation $\left(\mathrm{pM} \mathrm{leu} \mathrm{h}^{-1}\right)$ with time and depth at the midshelf site. Individual sampling depths are indicated by black dots. The left panels depict variation in abundance and the right panels variation in $\left[{ }^{3} \mathrm{H}\right]$-leu incorporation rate. The top 2 panels $(A, B)$ in the figures are based on 1997 data (El Niño conditions) and the 4 lower panels (C to F) are based on 1998 data (normal upwelling conditions). Elapsed time in hours is shown at the top, and day (clear bars) and night (dark bars) periods are shown at the bottom of each panel. Note that 1998 data are divided into 2 time periods: August 31 to September 5 (C,D) and September 19 to 20 (E,F). Because of change in water mass characteristics during the first 1998 sampling period, the August 31 to September 5 sampling data were further subdivided into the periods August 31 to September 2 and September 3 to 5 for calculation of average parameter values in Tables 1, 2 \& 4 
Table 2. Comparison of bacterial abundance, rates of substrate incorporation, cell-specific leucine incorporation rates (leucine specific activity [Leu SA], and the ratio between $\left[{ }^{3} \mathrm{H}\right]$-leu and $\left[{ }^{3} \mathrm{H}\right]$-thymidine (TdR) incorporation rates at the midshelf, slope, and gyre sites at 0 to $30 \mathrm{~m}$ and 50 to $80 \mathrm{~m}$ depth zones during September 1997 and September 1998. Data are mean $\pm 1 \mathrm{SD}$. 1998 data for the 0 to $30 \mathrm{~m}$ depth zone were separated into 3 time periods at the midshelf site: (a) August 31 to September 2, (b) September 3 to 5, and (c) September 19 to 20; and into 2 time periods at the slope site: (a) September 12 to 14, and (b) September 15 to 17

\begin{tabular}{|c|c|c|c|c|c|}
\hline Site & $\begin{array}{c}\text { Bacteria } \\
\left(10^{6} \text { cells ml }^{-1}\right)\end{array}$ & $\begin{array}{l}\text { Leu incorporation } \\
\qquad\left(\mathrm{pM} \mathrm{h}^{-1}\right)\end{array}$ & $\begin{array}{l}\text { TdR incorporation } \\
\qquad\left(\mathrm{pM} \mathrm{h} \mathrm{h}^{-1}\right)\end{array}$ & $\begin{array}{c}\text { Leu SA } \\
\left(10^{-21} \mathrm{~mol} \mathrm{cell}^{-1} \mathrm{~h}^{-1}\right)\end{array}$ & Leu:TdR \\
\hline \multicolumn{6}{|l|}{1997} \\
\hline \multicolumn{6}{|l|}{ Midshelf } \\
\hline $0-30 \mathrm{~m}$ & $1.25 \pm 0.20$ & $95 \pm 38$ & nd & $80 \pm 33$ & nd \\
\hline $50-80 \mathrm{~m}$ & $0.51 \pm 0.03$ & $7.9 \pm 1.4$ & & $15 \pm 3$ & \\
\hline \multicolumn{6}{|l|}{ Slope } \\
\hline $0-30 \mathrm{~m}$ & $1.27 \pm 0.38$ & $17 \pm 9$ & nd & $15 \pm 8$ & nd \\
\hline $50-80 \mathrm{~m}$ & $0.55 \pm 0.05$ & $2.7 \pm 1.5$ & & $5.2 \pm 3.3$ & \\
\hline \multicolumn{6}{|l|}{ Gyre } \\
\hline $0-30 \mathrm{~m}$ & $1.11 \pm 0.16$ & $15 \pm 8$ & nd & $14 \pm 8$ & nd \\
\hline $50-80 \mathrm{~m}$ & $0.72 \pm 0.27$ & $5.4 \pm 3.1$ & & $6.9 \pm 1.3$ & \\
\hline \multicolumn{6}{|l|}{1998} \\
\hline \multicolumn{6}{|l|}{ Midshelf } \\
\hline $0-30 \mathrm{~m}, \mathrm{a}$ & $0.73 \pm 0.11$ & $80 \pm 35$ & $2.9 \pm 1$ & $107 \pm 38$ & $28 \pm 8$ \\
\hline $0-30 \mathrm{~m}, \mathrm{~b}$ & $0.63 \pm 0.12$ & $14 \pm 6$ & $1 \pm 0.4$ & $22 \pm 8$ & $14 \pm 5$ \\
\hline $0-30 \mathrm{~m}, \mathrm{c}$ & $1 \pm 0.31$ & $59 \pm 21$ & nd & $60 \pm 23$ & nd \\
\hline \multicolumn{6}{|l|}{ Slope } \\
\hline $0-30 \mathrm{~m}, \mathrm{a}$ & $1.00 \pm 0.60$ & $30 \pm 15$ & $1.7 \pm 0.7$ & $37 \pm 14$ & $18 \pm 11$ \\
\hline $0-30 \mathrm{~m}, \mathrm{~b}$ & $1.60 \pm 0.36$ & $45 \pm 13$ & nd & $30 \pm 8$ & nd \\
\hline $50-80 \mathrm{~m}$ & $0.30 \pm 0.05$ & $3 \pm 0.9$ & $0.26 \pm 0.00$ & $9.1 \pm 4$ & $11 \pm 3$ \\
\hline \multicolumn{6}{|l|}{ Gyre } \\
\hline $0-30 \mathrm{~m}$ & $1.6 \pm 0.4$ & $33 \pm 11$ & $1.0 \pm 0.4$ & $21 \pm 3$ & $41 \pm 22$ \\
\hline $50-80 \mathrm{~m}$ & $0.45 \pm 0.08$ & $3.2 \pm 0.9$ & $0.42 \pm 0.14$ & $8 \pm 2.1$ & $8.4 \pm 2.9$ \\
\hline
\end{tabular}

through the sampling site, and both bacterial abundances and rates of activity dropped. We divided this continuous sampling effort into 2 distinct time periods (midshelf $\mathrm{a}$ and $\mathrm{b}$ ) to obtain average values for parameters shown in Tables 1 \& 2 .

Gasol et al. (1998) reported that for an open ocean site in the Mediterranean Sea, diel variations in bacterial growth appeared to correspond to diel variations in phytoplankton production (i.e., higher during the day). We examined our data sets for a similar diurnal pattern of activity. For 2 continuous sampling periods, which included a number of samples taken during the night as well as during the day, we pooled night (26 data points) and day (40 data points) measurements and compared the 2 data sets. However, we did not find evidence for significant day-night differences in bacterial abundance or in rates of leu incorporation.

Bacterial abundances varied within 1 order of magnitude, with low values of $\sim 0.2 \times 10^{6} \mathrm{cells} \mathrm{ml}^{-1}$ at depths of 70 to $80 \mathrm{~m}$ and high values of $>2 \times 10^{6}$ cells ml ${ }^{-1}$ at specific depths in the upper $30 \mathrm{~m}$. During the El Niño conditions that prevailed during late summer 1997 , bacterial abundances were uniform at all 3 sites and generally $>1 \times 10^{6}$ cells ml $^{-1}$ in surface waters (Table 2 ). During the normal upwelling conditions that prevailed in 1998, bacterial abundances in the surface layer were lower at the midshelf site and increased with distance offshore (Table 2). In the lower depth zone, below the mixed layer, bacterial abundances were low and uniform across sites and between years.

Bacterial activity, in terms of rates of incorporation of $\left[{ }^{3} \mathrm{H}\right]$-leu during the 1997 cruise, and of both $\left[{ }^{3} \mathrm{H}\right]-\mathrm{leu}$ and $\left[{ }^{3} \mathrm{H}\right]-\mathrm{TdR}$ incorporation rates during the 1998 cruise, was more variable and had more distinctive temporal and spatial patterns than bacterial abundance (Fig. 1, Table 2). [ $\left.{ }^{3} \mathrm{H}\right]$-leu incorporation rates varied over 2 orders of magnitude, from 1.5 to $240 \mathrm{pM}$ $\mathrm{h}^{-1}$. Both volumetric rates of substrate incorporation $\left(\mathrm{pM} \mathrm{h}^{-1}\right)$ and cell-specific activities $\left(10^{-21} \mathrm{~mol}\right.$ substrate cell $^{-1} \mathrm{~h}^{-1}$ ) were highest in the upper $30 \mathrm{~m}$ and lowest at the deepest depths sampled, 50 to $80 \mathrm{~m}$ (Table 2). Average rates of activity at the slope and gyre sites were 2 -fold higher in 1998 than in 1997. At the midshelf site in 1998, 3 discrete sampling periods yielded large differences in the average rate of $\left[{ }^{3} \mathrm{H}\right]-\mathrm{leu}$ incorporation, ranging from $80 \pm 35$ to $14 \pm 6 \mathrm{pM} \mathrm{h}^{-1}$ (Table 2).

The ratio of $\left[{ }^{3} \mathrm{H}\right]$-leu to $\left[{ }^{3} \mathrm{H}\right]-\mathrm{TdR}$ incorporation was also variable, with highest ratios during the first sampling period at the midshelf site (midshelf-a) and in the 

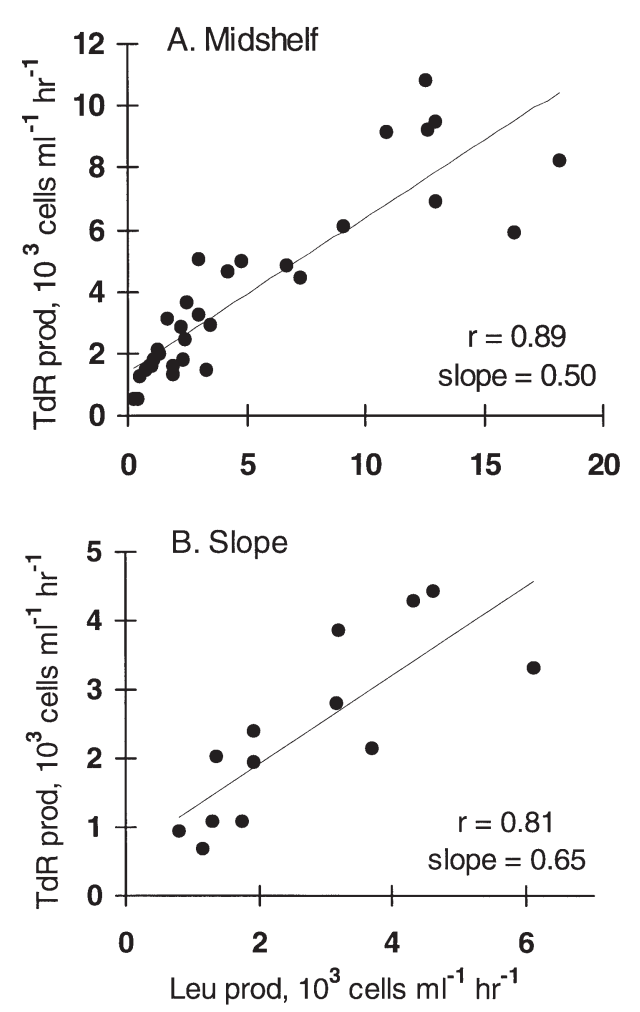

Fig. 2. Comparison of rate of production of bacterial cells $\left(10^{3}\right.$ cells $\left.\mathrm{ml}^{-1} \mathrm{~h}^{-1}\right)$, estimated by incorporation of $\left[{ }^{3} \mathrm{H}\right]-\mathrm{leu}$, with the rate estimated by incorporation of $\left[{ }^{3} \mathrm{H}\right]$-thymidine (TdR) using empirical conversion factors from Sherr et al. (1999a). (A) Midshelf site, where TdR production $=1.4+0.50$ leu production, $r=0.89, \mathrm{p}<0.001$; (B) slope site, where TdR production $=0.6+0.65$ leu production, $\mathrm{r}=0.81, \mathrm{p}<0.001$

0 to $30 \mathrm{~m}$ depth zone at the gyre site, and lowest ratios during the second sampling period at the midshelf site (midshelf-b) and in the 50 to $80 \mathrm{~m}$ depth zone at the slope and offshore site (Table 2). Regression analysis of the relation between estimates of rate of bacterial cell production estimated by either $\left[{ }^{3} \mathrm{H}\right]$-leu or $\left[{ }^{3} \mathrm{H}\right]-\mathrm{TdR}$ incorporation resulted in significant positive relations between the 2 estimates for the midshelf site and slope site (Fig. 2) but no strong relation at the gyre site $(r=0.31$, $\mathrm{p}=0.2)$. [ $\left.{ }^{3} \mathrm{H}\right]$-TdR-based estimates yielded lower rates of cell production than did $\left[{ }^{3} \mathrm{H}\right]-$ leu-based estimates; for the midshelf site, the regression relation of TdR:leu production was 0.50 and for the slope site, 0.65. Results of Spearman rank correlation analysis for all data in 1997 and in 1998 showed similar patterns for both years (Table 3). The distribution of bacterial biomass was positively correlated with temperature, and negatively correlated with depth and salinity. Bacterial activity was most highly correlated with chl a concentration and with bacterial bio- mass, and negatively correlated with depth. In 1998, neither bacterial parameter was significantly related with DOC concentration.

We further explored the relation between bacterial activity $\left(\left[{ }^{3} \mathrm{H}\right]-l e u\right.$ incorporation rate) and phytoplankton stocks (chl a concentration) by regression analysis of these parameters for data collected at individual sampling sites. In 1997, there was no difference in the relation between activity and phytoplankton stocks at the slope and gyre sites, so the data for these sites were pooled for a single regression analysis. There were highly significant relations between bacterial $\left[{ }^{3} \mathrm{H}\right]-\mathrm{leu}$ incorporation rates and chl a concentrations at the midshelf site in both years (1997: pM leu h $\mathrm{h}^{-1}=19+29 \mu \mathrm{g}$ chl $a l^{-1}, \mathrm{r}=0.80, \mathrm{p}<0.001$; and 1998: $\mathrm{pM} \mathrm{leu} \mathrm{h}^{-1}=7.7+$

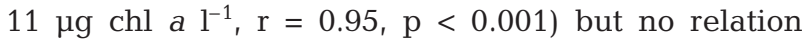
between the 2 parameters at the slope and gyre sites in 1997 or at the slope site in 1998. However, in 1998 we did find a significant relation between activity and chl a concentrations at the gyre site $\left(\mathrm{pM}\right.$ leu $\mathrm{h}^{-1}=-1.6+$ $63 \mu \mathrm{g} \mathrm{chl} \mathrm{a} \mathrm{l}^{-1}, \mathrm{r}=0.70, \mathrm{p}<0.001$ ).

\section{DISCUSSION}

\section{Mesoscale variability in bacterial abundance and activity}

There was a considerable amount of variation in the concentration of bacteria and in the rate of bacterial activity as assayed by incorporation of radiolabeled substrate over depth scales of several to 10 s of meters and over time scales of hours to days at 3 sites sampled off the Oregon coast at the same season (late summer) in 2 consecutive years. There were also isolated 'hot spots' of bacterial abundance and activity at specific

Table 3. Spearman rank correlation coefficients between bacterial biomass ( $\mathrm{mg} \mathrm{C}^{-1}$ ) and activity (leucine incorporation rates, $\mathrm{pM} \mathrm{h}^{-1}$ ) and environmental parameters in 1997 and 1998. Bold values are significant at a level of $p<0.01$. The number of paired values in each data set ranged from 53 to 113 . All data were transformed to natural logarithms before statistical analysis

\begin{tabular}{|c|c|c|c|c|}
\hline \multirow[t]{2}{*}{ Parameter } & \multicolumn{2}{|c|}{ September 1997} & \multicolumn{2}{|c|}{ September 1998} \\
\hline & $\begin{array}{c}\text { Bacterial } \\
\text { biomass }\end{array}$ & $\begin{array}{c}\text { Bacterial } \\
\text { activity }\end{array}$ & $\begin{array}{c}\text { Bacterial } \\
\text { biomass }\end{array}$ & $\begin{array}{c}\text { Bacterial } \\
\text { activity }\end{array}$ \\
\hline Depth & -0.74 & -0.55 & -0.61 & -0.57 \\
\hline Temperature & 0.71 & 0.28 & 0.68 & 0.34 \\
\hline Salinity & -0.66 & -0.22 & -0.61 & -0.24 \\
\hline Nitrate & -0.46 & -0.02 & -0.36 & -0.15 \\
\hline Phosphate & -0.62 & -0.14 & -0.51 & -0.22 \\
\hline Chl & 0.34 & 0.65 & 0.51 & 0.83 \\
\hline $\mathrm{DOC}(\mu \mathrm{M})$ & nd & nd & 0.12 & 0.11 \\
\hline Bacterial biomass & - & 0.57 & - & 0.68 \\
\hline Bacterial activity & 0.57 & - & 0.68 & - \\
\hline
\end{tabular}


times and depths (examples shown in Fig. 1). A clear pattern for all sites and both years was that of lower bacterial abundances and lower rates of total and of cell-specific activity at depths below the euphotic zone (Fig. 1, Table 2). [ $\left.{ }^{3} \mathrm{H}\right]$-leu incorporation rates were up to 10 -fold lower in the 50 to $80 \mathrm{~m}$ depth zone than in the 0 to $30 \mathrm{~m}$ depth zone. Since bacterial abundances also decreased with depth, cell-specific activity rates were only 2- to 5 -fold lower at depth than in surface waters (Table 2).

The excursions of bacterial activity were greatest at the midshelf site and were especially marked during 1998 (Fig. 1C to F), varying $~ 100$-fold, from $<20$ to $>200 \mathrm{pM} \mathrm{leu} \mathrm{h}^{-1}$. Since nutrient concentrations were high at this site in 1998 (Table 1), we infer that the temporal patchiness, both of chl a concentrations (Table 1) and of bacterial abundance and activity (Fig. 1C to F, Table 2), was related to development of phytoplankton blooms in newly upwelled water as well as to variability in water masses in the system. For example, the lower salinity and nutrient concentrations of the midshelf-c period (Table 1) may have resulted from advection of a water mass influenced by the Columbia River plume into the sampling site. Bacterial $\left[{ }^{3} \mathrm{H}\right]$-leu incorporation rates and cell-specific activities were lowest during the low chlorophyll, high nutrient conditions of the midshelf-b period and highest during the higher chlorophyll conditions of the midshelf-a period (Table 2).

Patterns of abundance and of activity were often dissimilar, which was reflected in the fact that correlation coefficients for the relation between $\left[{ }^{3} \mathrm{H}\right]$-leu incorporation rates and bacterial cell abundance were smaller than those for the relation between incorporation rates and chl a concentrations (Table 3). The variability we observed over short time periods and between time periods separated by a few hours or a few days in the upper water column at the midshelf and slope sites suggests that sampling for bacterial abundance and activity in this region is not straightforward. Repeated sampling at single locations is apparently necessary to adequately characterize these properties in such a dynamic system.

\section{Effect of El Niño conditions}

In addition to considerable within-site variability, there were differences between the $2 \mathrm{yr}$ in distribution of bacterial biomass and activity. During the $1997 \mathrm{El}$ Niño conditions, surface water temperatures were higher and nutrient concentrations lower at the midshelf site than the more typical upwelling conditions in 1998 (Table 1). Despite the differences in environmental parameters, rates of $\left[{ }^{3} \mathrm{H}\right]$-leu incorporation at the midshelf site were high in both years (Table 2). In contrast, rates of bacterial activity were on average 2 -fold lower at the slope and offshore sites in September 1997 than in September 1998 (Table 2), even though temperatures as well as nutrient and chl a concentrations in surface waters were not very different at these sites for the $2 \mathrm{yr}$ (Table 1).

Our data thus suggest that, in terms of bacterioplankton activity, El Niño conditions had a greater effect on the more oligotrophic offshore systems than on the mesotrophic to eutrophic shelf system. This is somewhat counter-intuitive, as one would expect that the main driver of bacterial activity in an aquatic ecosystem would be the quantitative amount of phytoplankton biomass and carbon production rates (Cole et al. 1988, Ducklow 2000). In fact, the results of our correlation analysis indicated that, for the entire data sets collected in each year, bacterial activity, as assessed by rates of $\left[{ }^{3} \mathrm{H}\right]$-leu incorporation, was more strongly related to phytoplankton biomass (chl a concentration) than to other environmental parameters (Table 3).

The growth and activity rates of heterotrophic bacteria are also affected by temperature (White et al. 1991, Tibbles 1996). However, Rivkin et al. (1996) reviewed the literature on bacterial activities in various regions of the sea and concluded that temperature did not have a substantial effect on in situ bacterioplankton growth rates. The results of our correlation analysis showed an insignificant correlation of bacterial $\left[{ }^{3} \mathrm{H}\right]$-leu incorporation rates with temperature in 1997 and only a weak positive relation between the 2 variables in 1998 (Table 3). We also found no relation between bacterial activity and concentration of DOM in 1998 (Table 3), although DOM is considered to be the main organic carbon resource for bacterioplankton (Williams 2000).

\section{Magnitude of biomass production and growth rates in the Northwest Pacific off Oregon}

This data set is a result of the first detailed analysis of the distribution and rates of bacterial activity in the Northeast Pacific Ocean off Oregon. The region sampled in this study included the coastal upwelling system on the continental shelf, a transitional region at the shelf break, and the edge of the generally oligotrophic central North Pacific gyre. For the upper $30 \mathrm{~m}$ of the midshelf site, the rate of biomass production estimated from incorporation of $\left[{ }^{3} \mathrm{H}\right]$-leu averaged $5.7 \pm 2.3 \mu \mathrm{g} \mathrm{C}$ $\mathrm{l}^{-1} \mathrm{~d}^{-1}$ in 1997 and $4.8 \pm 2.1 \mu \mathrm{g} \mathrm{C} \mathrm{l}^{-1} \mathrm{~d}^{-1}$ in 1998 (Table 4). These rates corresponded to in situ bacterial growth rates on the order of $0.3 \mathrm{~d}^{-1}$, equivalent to an assemblage $T_{\mathrm{d}}$ of about $3 \mathrm{~d}$. Even though the midshelf system was characterized by fairly high nutrient and 
Table 4. Comparison of bacterial productivity, growth rates, and doubling times $\left(T_{\mathrm{d}}\right)$, based on rates of $\left[{ }^{3} \mathrm{H}\right]$-leu incorporation at the midshelf, slope, and gyre sites in 0 to $30 \mathrm{~m}$ and 50 to $80 \mathrm{~m}$ depth zones during September 1997 and September 1998. Data are mean \pm 1 SD. 1998 data for the 0 to $30 \mathrm{~m}$ depth zone were separated into 3 time periods at the midshelf site: (a) August 31 to September 2, (b) September 3 to 5, and (c) September 19 to 20; and into 2 time periods at the slope site: (a) September 12 to 14, and (b) September 15 to 17

\begin{tabular}{|c|c|c|c|}
\hline & \multicolumn{3}{|c|}{ Leucine incorporation } \\
\hline & $\begin{array}{l}\text { Productivity } \\
\left(\mu \mathrm{C}^{-1} \mathrm{~d}^{-1}\right)\end{array}$ & $\begin{array}{c}\text { Growth rate } \\
\left(\mathrm{d}^{-1}\right)\end{array}$ & $\begin{array}{l}T_{\mathrm{d}} \\
\text { (d) }\end{array}$ \\
\hline \multicolumn{4}{|l|}{1997} \\
\hline \multicolumn{4}{|l|}{ Midshelf } \\
\hline $0-30 \mathrm{~m}$ & $5.7 \pm 2.3$ & $0.31 \pm 0.09$ & $2.7 \pm 1$ \\
\hline $50-80 \mathrm{~m}$ & $0.47 \pm 0.09$ & $0.07 \pm 0.02$ & $10.3 \pm 2.4$ \\
\hline \multicolumn{4}{|l|}{ Slope } \\
\hline $0-30 \mathrm{~m}$ & $0.95 \pm 0.49$ & $0.03 \pm 0.01$ & $34 \pm 13$ \\
\hline $50-80 \mathrm{~m}$ & $0.15 \pm 0.09$ & $0.01 \pm 0.005$ & $120 \pm 66$ \\
\hline \multicolumn{4}{|l|}{ Gyre } \\
\hline $0-30 \mathrm{~m}$ & $0.56 \pm 0.32$ & $0.02 \pm 0.01$ & $39 \pm 13$ \\
\hline $50-80 \mathrm{~m}$ & $0.21 \pm 0.12$ & $0.01 \pm 0.002$ & $92 \pm 22$ \\
\hline \multicolumn{4}{|l|}{1998} \\
\hline Midshelf & $4.8 \pm 2.1$ & $0.28 \pm 0.09$ & $3 \pm 1.2$ \\
\hline $0-30 \mathrm{~m}, \mathrm{a}$ & $2.6 \pm 2.1$ & $0.06 \pm 0.02$ & $14.6 \pm 6.2$ \\
\hline $0-30 \mathrm{~m}, \mathrm{~b}$ & $3.5 \pm 1.3$ & $0.16 \pm 0.06$ & $5.1 \pm 1.8$ \\
\hline $0-30 \mathrm{~m}, \mathrm{c}$ & & & \\
\hline \multicolumn{4}{|l|}{ Slope } \\
\hline $0-30 \mathrm{~m}, \mathrm{a}$ & $1.7 \pm 0.8$ & $0.10 \pm 0.04$ & $8.4 \pm 2.9$ \\
\hline $0-30 \mathrm{~m}, \mathrm{~b}$ & $2.3 \pm 0.6$ & $0.09 \pm 0.02$ & $9.1 \pm 2.3$ \\
\hline $50-80 \mathrm{~m}$ & $0.17 \pm 0.05$ & $0.03 \pm 0.01$ & $34 \pm 13$ \\
\hline \multicolumn{4}{|l|}{ Gyre } \\
\hline $0-30 \mathrm{~m}$ & $1.3 \pm 0.4$ & $0.04 \pm 0.01$ & $19 \pm 4$ \\
\hline $50-80 \mathrm{~m}$ & $0.12 \pm 0.05$ & $0.02 \pm 0.004$ & $53 \pm 20$ \\
\hline
\end{tabular}

chl a concentrations during our late summer cruises, these productivities and growth rates are lower than would be expected for a mesotrophic to eutrophic marine ecosystem. Ducklow \& Carlson (1992) reviewed all available data sets on bacterial production in marine systems and reported average rates for upwelling systems of 19 to $46 \mu \mathrm{C} \mathrm{C}^{-1} \mathrm{~d}^{-1}$, although values $<5 \mu \mathrm{g} \mathrm{C}^{-1} \mathrm{~d}^{-1}$ were occasionally found. Our midshelf bacterial production rates were similar to those found during the spring bloom in the eastern North Atlantic Ocean, during which chlorophyll concentrations were 1 to $3 \mu \mathrm{g} \mathrm{l}^{-1}$, bacterial productivities

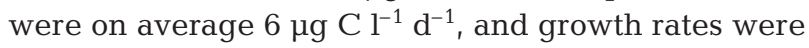
$\sim 0.3 \mathrm{~d}^{-1}$ in the upper $50 \mathrm{~m}$ (Ducklow et al. 1993).

The production rates found in the upper water column of the slope and gyre sites were several-fold lower than midshelf rates: on average $<1 \mu \mathrm{g} \mathrm{Cl}^{-1} \mathrm{~d}^{-1}$ in 1997 and $<2 \mu \mathrm{g} \mathrm{C} \mathrm{l}^{-1} \mathrm{~d}^{-1}$ in 1998, with calculated bacterial growth rates of 0.02 to $0.10 \mathrm{~d}^{-1}$ and assemblage $T_{\mathrm{d}}$ of 8 to $40 \mathrm{~d}$ (Table 4 ). These rates of bacterial production are at the low end of the range of rates reported for open ocean systems (Ducklow \& Carlson 1992). However, values for bacterial production in open ocean systems with phytoplankton stocks $<1 \mu \mathrm{g} \mathrm{chl} \mathrm{a} \mathrm{l}^{-1}$ are similar to our rates. For example, Kirchman et al. (1991) found bacterial production rates of 0.5 to $2.0 \mu \mathrm{g} \mathrm{C} \mathrm{l}^{-1} \mathrm{~d}^{-1}$ and growth rates of 0.02 to $0.10 \mathrm{~d}^{-1}$ in low chl a (0.2 to $\left.0.4 \mu \mathrm{g} \mathrm{l}^{-1}\right)$ surface waters of the subarctic Pacific in late summer. Subsequently, Kirchman et al. (1995) reported average production rates of $\sim 1$ to $1.5 \mu \mathrm{g} \mathrm{C}^{-1} \mathrm{~d}^{-1}$ and growth rates of 0.11 to $0.16 \mathrm{~d}^{-1}$ in the upper 50 to $120 \mathrm{~m}$ of the water column of the equatorial Pacific. Chl a concentrations were also low, on average $\sim 0.2 \mu \mathrm{g} \mathrm{l}^{-1}$, in these waters.

\section{Relation between $\left[{ }^{3} \mathrm{H}\right]-$ leu and $\left[{ }^{3} \mathrm{H}\right]-\mathrm{TdR}$ incorporation rates}

In 1998, we obtained rates of bacterial activity and calculated bacterial production rates based on incorporation of both $\left[{ }^{3} \mathrm{H}\right]$-leu and $\left[{ }^{3} \mathrm{H}\right]-\mathrm{TdR}$ (Tables $2 \& 4$ ). Wide variations in the ratio of leu:TdR incorporation have been found in a number of studies (Chin-Leo \& Kirchman 1990, Tibbles 1996, Shiah \& Ducklow 1997, Sherr et al. 1999a, Ducklow 2000). A leu:TdR incorporation ratio of about 16 should imply balanced growth; i.e., bacteria are synthesizing protein and DNA at approximately the same rate (Ducklow 2000). Higher or lower ratios may suggest unbalanced growth. In our data set, the greatest range of leu:TdR ratios occurred at the gyre site, with values of $8.4 \pm 2.9$ in the 50 to $80 \mathrm{~m}$ depth zone and 41 \pm 22 in the 0 to $30 \mathrm{~m}$ depth zone (Table 2). In incubation experiments carried out at the 3 sampling sites during 1998, we found that leu:TdR ratios increased with a shift-up of bacteria to rapid growth rate, from low values of 8.6 to 15 at the beginning of the experiments to 33 to 36 after 50 to $60 \mathrm{~h}$ (Sherr et al. 1999a). Varying relations between leu:TdR ratios and temperature have been reported in both open ocean and estuarine systems (Tibbles 1996, Shiah \& Ducklow 1997). We found no relation between these 2 parameters in our incubation study, and there was no obvious relation between leu:TdR ratios and temperature in the data sets presented here. Gasol et al (1998) found very high ratios, $>100$, below the euphotic zone in the Mediterranean Sea, which is in contrast to our finding of lowest values, $<15$, at subsurface depths (Table 2). There does not appear to be a consistent pattern of leu:TdR ratios in different marine systems (Ducklow 2000), but these ratios may offer useful information when applied to one particular system. In Oregon shelf and offshore 
waters, bacterial assemblages showed a generally positive relation between leu:TdR ratios and rates of substrate incorporation (Table 2; Sherr et al. 1999a). What the variation in the ratio of leu:TdR incorporation means in terms of specific physiological responses of bacterioplankton needs further investigation.

For the 1998 data, we were able to derive independent estimates of rates of bacterial cell and biomass production based on $\left[{ }^{3} \mathrm{H}\right]$-leu and $\left[{ }^{3} \mathrm{H}\right]$-TdR incorporation rates (Fig. 2, Table 4) using conversion factors empirically determined for each site (Sherr et al. 1999a). There were highly significant $(p<0.001)$ relations between the 2 estimates of cell production rate for the midshelf and slope (Fig. 2) but not for the gyre data sets. However, the linear relation of TdR production:leu production was $<1,0.50$ for the midshelf data and 0.65 for the slope data. Thus, thymidinebased rates of biomass production were generally lower than leu-based estimates of production in this study (Table 4).

\section{CONCLUSIONS}

We found a high degree of variation in bacterial activity at 3 sites in the Northeast Pacific Ocean off the Oregon coast. Short-term changes in rates of bacterial substrate incorporation were greatest at the midshelf site (Fig. 1), which is part of a dynamic upwelling ecosystem in which there is significant spatial and temporal variability in mesoscale circulation (Huyer \& Smith 1985, Huyer 1990). There were also betweenyear differences in bacterial activity in the upper $30 \mathrm{~m}$ of the water column at the 2 outer sites. At both the slope and gyre edge sites during the more normal conditions of 1998, average rates of bacterial leu incorporation and cell-specific activities were about twice as high in the upper $30 \mathrm{~m}$ of the water column than during the El Niño conditions of 1997 (Table 2), even though environmental conditions were not very different at these sites in the 2 years (Table 1 ).

Our results confirm the previous finding that, in aquatic systems, the degree of variation in rate of bacterial activity, measured per unit volume of water or on a cell-specific basis, is greater by 1 or 2 orders of magnitude than the variation in bacterial abundance (Cole et al. 1988, Ducklow 2000). The changes we observed in bacterial activity over time scales of hours and depth scales of meters support the idea that in situ bacterioplankton assemblages can undergo relatively rapid 'shifts-up' or 'shifts-down' in metabolism depending on local environmental conditions (del Giorgio \& Cole 2000). We have previously shown metabolic shift-up for bacterioplankton in surface water at each of the sampling sites over time scales of 19 to $28 \mathrm{~h}$ during incubation experiments (Sherr et al. 1999a). In the entire data sets of both years, rates of bacterial activity were most strongly related to standing stock of phytoplankton (chl a concentration) (Table 3). Substrate for bacterial growth can be provided by phytoplankton release of labile DOM or by production of DOM during trophic interactions in pelagic food webs (Jumars et al. 1989, Nagata 2000). The magnitude of labile DOM flux from both pathways should be, in general, positively related to amount of phytoplankton biomass.

However, the present results, combined with those of Sherr et al. (1999a), also suggest that bacterioplankton in surface waters of the Northeast Pacific are fairly inactive compared with their potential for growth. The cell-specific activities found in incubation experiments were 6- to 30-fold higher than cell-specific activities observed for in situ bacteria at the 3 sampling sites (Sherr et al. 1999a). In that study, empirically determined growth rates for incubated bacteria ranged from $0.4 \mathrm{~d}^{-1}$ for slope and gyre to $0.8 \mathrm{~d}^{-1}$ for midshelf assemblages. In situ leu incorporation rates reported here imply growth rates in the upper $30 \mathrm{~m}$ of only 0.02 to $0.1 \mathrm{~d}^{-1}$ for slope and gyre bacterioplankton and about $0.3 \mathrm{~d}^{-1}$ for midshelf bacterioplankton. On the basis of average cell-specific activities, bacterioplankton assemblages were, in aggregate, least active at depths below the euphotic zone (50 to $80 \mathrm{~m}$ ) and in surface waters with lower phytoplankton stocks (Table 2). Our data support the view that in situ pelagic bacteria are ordinarily relatively inactive but that at least some of the bacterial populations in a community can respond to enhanced substrate availability on a time-scale of hours by increasing rates of cell-specific activity and growth (Sherr et al. 1999b, del Giorgio \& Cole 2000).

Acknowledgements. Funding for this research was provided by NSF grant OCE-9618137 to T.J.C., B.F.S., and E.B.S. and by NSF grants OCE-9633712 and OCE-0002236 to E.B.S. and B.F.S. We thank the captain and crew of RV 'Wecoma' for their expert support of our sampling program and Joe Jennings, Karen Thompson, and Crystal Tilton Sigmon for technical assistance.

\section{LITERATURE CITED}

Bell RT (1993) Estimating production of heterotrophic bacterioplankton via incorporation of tritiated thymidine. In: Kemp P, Sherr B, Sherr E, Cole JJ (eds) Handbook of methods in aquatic microbial ecology. Lewis Publishers, Boca Raton, p 495-503

Billen G, Servais P, Becquevort S (1990) Dynamics of bacterioplankton in oligotrophic and eutrophic aquatic environments: bottom-up or top-down control? Hydrobiologia 207:37-42

Carlson C, Ducklow HW, Sleeter TD (1996) Stocks and dynamics of bacterioplankton in the northwestern Sargasso Sea. Deep-Sea Res II 43:491-516 
Chin-Leo G, Kirchman DL (1990) Unbalanced growth in natural assemblages of marine bacterioplankton. Mar Ecol Prog Ser 63:1-8

Cole JJ, Findlay S, Pace ML (1988) Bacterial production in fresh and saltwater: a cross system overview. Mar Ecol Prog Ser 43:1-10

del Giorgio PA, Cole JJ (2000) Bacterial energetics and growth efficiencies. In: Kirchman DL (ed) Microbial ecology of the oceans. Wiley-Liss, New York, p 289-325

Ducklow HW (1992) Factors regulating bottom-up control of bacterial biomass in open ocean communities. Arch Hydrobiol Beih 37:207-217

Ducklow HW (2000) Bacterial production and biomass in the oceans. In: Kirchman DL (ed) Microbial ecology of the oceans. Wiley-Liss, New York, p 85-120

Ducklow HW, Carlson CA (1992) Oceanic bacterial production. Adv Microb Ecol 12:113-181

Ducklow HW, Shiah FK (1993) Estuarine bacterial production. In: Ford $\mathrm{T}$ (ed) Aquatic microbiology: an ecological approach. Blackwell, London, p 261-284

Ducklow HW, Kirchman DL, Quinby HL, Carlson CA, Dam HG (1993) Stocks and dynamics of bacterioplankton carbon during the spring phytoplankton bloom in the eastern North Atlantic Ocean. Deep-Sea Res II 42:621-638

Gasol JM, Doval MD, Pinhassi J, Calderon-Paz JI, GuixaBoixareu N, Vaque D, Pedros-Alio C (1998) Diel variations in bacterial heterotrophic activity and growth in the northwestern Mediterranean Sea. Mar Ecol Prog Ser 164: $107-124$

Gordon LI, Jennings JC, Ross AR, Krest JM (1995) A suggested protocol for continuous flow automated analysis of seawater nutrients (phosphate, nitrate, nitrite, and silicic acid) in the WOCE hydrographic program and the Joint Global Ocean Fluxes Study. OSU College of Oceanography Descriptive Chemistry. Oceanography Group Technical Report 93-1 (rev)

Huyer A (1990) Shelf circulation. In: Le Menhaute B, Hanes DM (eds) The sea, Vol 9. Ocean engineering science. Wiley, New York, p 423-466

Huyer A, Smith RL (1985) The signature of El Niño off Oregon, 1982-83. J Geophys Res 90:7133-7143

Huyer A, Fleischbein J, Barth JA, Kosro PM, Smith RL (1998) The coastal ocean off Oregon and Northern California during the 1997-98 El Niño, Part 1: Temperature, salinity, and geostrophic velocity fields. EOS Trans Am Geophys Union 79(Suppl F):485

Jumars PA, Penry DL, Baross JA, Perry MJ, Frost BW (1989) Closing the microbial loop: dissolved carbon pathways to heterotrophic bacteria from incomplete ingestion, digestion and absorption in animals. Deep-Sea Res 36:483-495

Kirchman DL, Keil RG, Simon M, Welschmeyer NA (1991) Biomass and production of heterotrophic bacterioplankton in the oceanic subarctic Pacific. Deep-Sea Res I 40: 967-988

Kirchman DL, Rich JH, Barber RT (1995) Biomass and biomass production of heterotrophic bacteria along $140^{\circ} \mathrm{W}$ in

Editorial responsibility: James Hollibaugh,

Athens, Georgia, USA the equatorial Pacific: effect of temperature on the microbial loop. Deep-Sea Res II 42:621-639

Kosro PM, Huyer A, Smith RL (1998) The coastal ocean off Oregon and Northern California during the 1997-98 El Niño, Part 2: Surface and subsurface currents. EOS Trans Am Geophys Union 79(Suppl F):485

Nagata T (2000) Production mechanisms of dissolved organic matter. In: Kirchman DL (ed) Microbial ecology of the oceans. Wiley-Liss, New York, p 121-152

Pace ML, Cole JJ (1994) Comparative and experimental approaches to top-down and bottom-up regulation of bacteria. Microb Ecol 28:181-193

Parsons TR, Maita Y, Lalli CM (1984) A manual of chemical and biological methods for seawater analysis. Pergamon Press, Toronto

Rivkin RB, Anderson M, Lajzerowicz C (1996) Microbial processes in cold oceans: I. Relationship between temperature and bacterial growth rate. Aquat Microb Ecol 10: 243-254

Sherr EB, Sherr BF, Sigmon CT (1999a). Activity of marine bacteria under incubated and in situ conditions. Aquat Microb Ecol 20:213-233

Sherr BF, del Giorgio P, Sherr EB (1999b) Estimating abundance and single-cell characteristics of actively respiring bacteria via the redox dye, CTC. Aquat Microb Ecol 18: 117-131

Shiah FK, Ducklow HW (1997) Bacterioplankton growth responses to temperature and chlorophyll variations in estuaries measured by thymidine:leucine incorporation ratio. Aquat Microb Ecol 13:151-159

Smith DC, Azam F (1992) A simple, economical method for measuring bacterial protein synthesis rates in seawater using 3H-leucine. Mar Microb Food Webs 6:107-114

Suzuki MT, Sherr EB, Sherr BF (1993) DAPI direct counting underestimates bacterial abundances and average cell size compared to AO direct counting. Limnol Oceanogr 38:1566-1570

Tibbles BJ (1996) Effects of temperature on the incorporation of leucine and thymidine by bacterioplankton and bacterial isolates. Aquat Microb Ecol 11:239-250

Wheeler PA, Corwith HL (1999) Nutrient distributions off the coast of Oregon during El Niño and normal upwelling conditions. Monterey Bay El Niño Workshop, December 1999

Wheeler PA, Hill J (1998) Biological effects of the 1997-1998 El Niño event off Oregon: nutrient and chlorophyll distributions. PICES VII Annual Meeting, Fairbanks, Alaska, Oct 17 to 24 (Abstract)

White PA, Kalff J, Rasmussin JB, Gasol JM (1991) The effect of temperature and algal biomass on bacterial production and specific growth rate in freshwater and marine habitats. Microb Ecol 21:99-118

Williams PJleB (2000) Heterotrophic bacteria and the dynamics of dissolved organic material. In: Kirchman DL (ed) Microbial ecology of the oceans. Wiley-Liss, New York, p 153-200

Submitted: October 2, 2000; Accepted: June 8, 2001

Proofs received from author(s): July 24, 2001 